\title{
Prototype measuring of erosion and currents under the keel of a sailing ship in a canal
}

\author{
K. Dorst \\ Infram and Rijkswaterstaat, Utrecht, Netherlands \\ D.J. Meys \\ Rijkswaterstaat, Utrecht, Netherlands \\ M. Schroevers \\ Deltares, Delft, Netherlands
}

H.J. Verheij

Delft University of Technology \& Deltares, Delft, Netherlands

ABSTRACT: A full scale experiment with a deep loaded push-tow barge combination was carried out in the Juliana Canal to determine the stability of a canal bed against future ship-induced loads. The resulting under keel currents and the subsequent bed erosion were monitored and analyzed. Clearly, the results showed that in the future the canal bed will be instable. The observed bed lowering could be estimated with a time/dependent scour prediction formula. The results of the observed flow velocities under the ship's keel were comparable with measured flow velocities in small-scale experiments.

\section{INTRODUCTION}

The Juliana Canal in the Netherlands is being prepared to accommodate larger and deeper loaded commercial inland vessels, such as large inland tankers and push-tow barge combinations. The canal lies higher than the surrounding area and has to be kept (nearly) watertight. In the 1930's this was achieved by placing a $60 \mathrm{~cm}$ thick layer of clay at the bottom of the canal, which was covered by a 40 $\mathrm{cm}$ layer of gravel. The gravel reduces the impact of ship-induced currents on the clay layer and should protect it from erosion. To reach the required depth, recently the canal has been dredged over some length and also the top layer of gravel had to be removed partly, leaving about $10 \mathrm{~cm}$ of gravel at some locations. The clay layer is left untouched. The stability of the remaining gravel and clay bed against future hydraulic loads induced by commercial inland ships was questioned.

Estimations on the currents underneath ships and subsequent erosion based on rules of thumb, mathematical modelling and scale modelling were considered not sufficient reliable to predict the stability or erodibility of the remaining gravel and clay bed. The bandwidth in the predictions of the flow velocities is too large which is enhanced by the variability in the bed material both in composition as compactness.

Therefore, a full-scale measurement campaign was performed to determine the stability or erodibility. In a prototype experiment the necessary hydraulic loads are created by a real vessel under controlled conditions. In this case a fully loaded push-tow barge combination (Sandra F) of 110 meters long, 11 meters wide, and a draught up to $3.5 \mathrm{~m}$ sailed through a 45 meter wide and approx.5 $\mathrm{m}$ deep part of the canal at full throttle (speed 2.0 to $2.3 \mathrm{~m} / \mathrm{s}$ ).

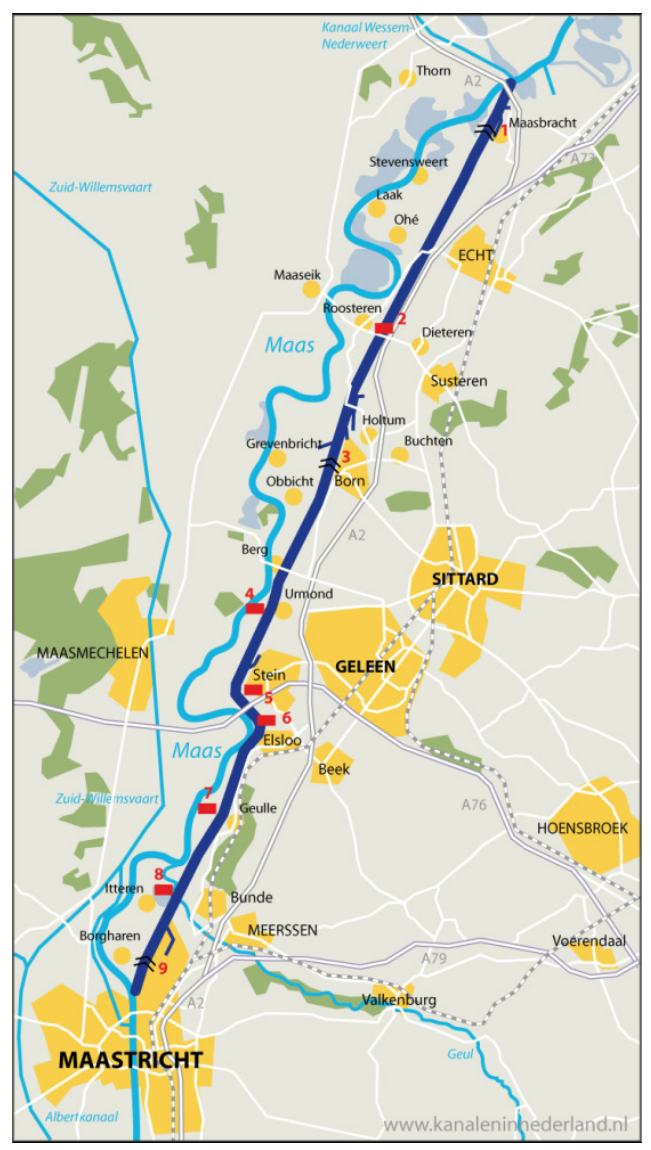

Figure 1. Map with Juliana Canal (dark blue) and the Meuse River (light blue). 


\section{UPGRADING JULIANA CANAL}

The Juliana Canal is a $36 \mathrm{~km}$ long canal located in the south of the Netherlands. It was constructed in the 1920's-1930's. The canal runs from the city of Maastricht to Maasbracht providing an alternative shipping route to an unnavigable part of the river Meuse. Over the $36 \mathrm{~km}$ the canal drops by $25 \mathrm{me}-$ ters. The water level is maintained by a series of locks. On average there is a Northward discharge of $15 \mathrm{~m} / \mathrm{s}^{3}$. The amount of discharge depends on the water availability and lock operation.

The Juliana Canal is as a part of the Meuse Corridor an important route for inland vessels and connects Rotterdam with the southern part of the Netherlands and Belgium.

To enable bigger and deeper loaded ships to use the Meuse Corridor and to approve the navigability currently the dimensions of the canal are being enlarged. This makes the canal navigable for CEMT class $\mathrm{Vb}$ with draught limitation of $3.5 \mathrm{~m}$.

\section{SHIP-INDUCED FLOW VELOCITIES}

As a ship sails through a canal it pushes away the water which will flow around and underneath the ship. This current is called return current. Simultaneously, a water level draw down occurs due to the Bernoulli effect. This causes the ship "sucked down" towards the canal bed, which is called the sinkage. In general, draw down and sinkage are assumed to be equal. In 1949 Schijf (1949) introduced a onedimensional approach to estimate the draw down and the flow velocities in the return current using the dimensions of the canal and the ship, the continuity equation and the Bernoulli equation.

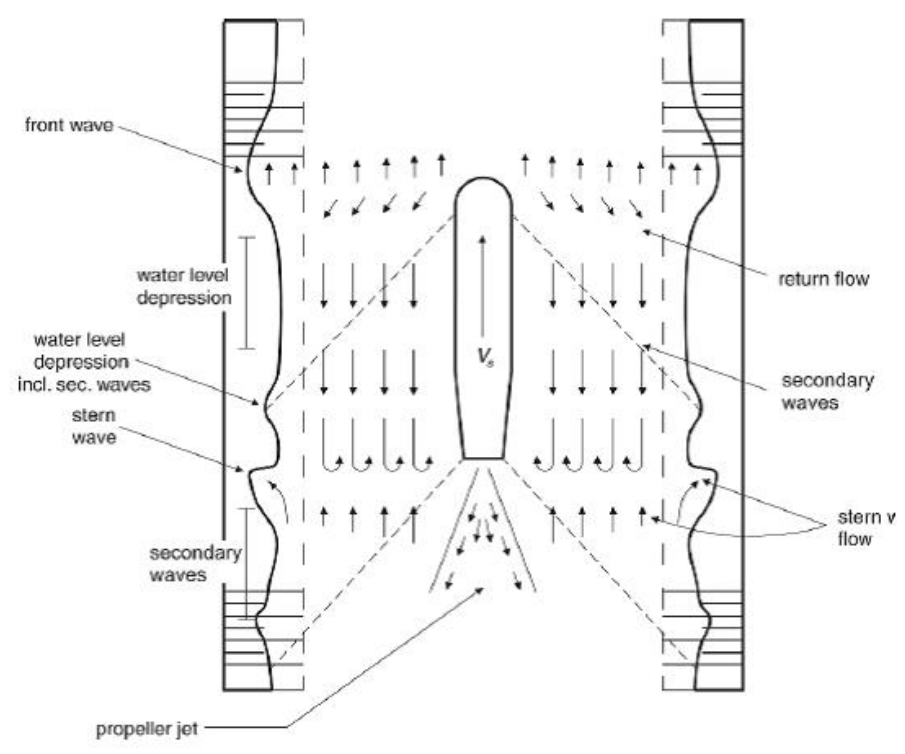

Figure 2. Currents and waves induced by a ship sailing in a canal.
By using equations mentioned in the Rock Manual (CUR/CIRIA/CETMEF, 2007) the average return current around the ship can be calculated. However, the currents underneath the ship will be higher than the average value of the return current and are the prime cause of bed erosion induced by ships. From scale model measurements in the 1980's at Delft Hydraulics, see Stolker \& Verheij (2006) a ratio between the maximum and the average return current $\left(\mathrm{U}_{\mathrm{R}}\right)$ during a passage was established as

$$
U_{R \max }=\alpha \cdot U_{R}
$$

with the ratio $\alpha \approx 1.5-2$

More recent research (Stolker \& Verheij, 2006) and (Lenselink, 2011) showed a wider range in ratio's ranging from 1 to 5 and an average of 1.5. Recent scale model tests by Robijns (2014) confirm the high ratio for velocities under the keel at small under keel clearances.

Note: Propeller wash is the dominant factor for erosion at locations where ships accelerate, decelerate or adjust course using side- or bow thrusters, but propeller wash does not play a significant role in straight stretches of a canal where ships normally sail with a speed higher than $1.5 \mathrm{~m} / \mathrm{s}$.

During the passage of the ship shape and character of the velocity profile change significantly. At the bow the water is forced to flow either underneath the ship or sideways. The downward flow contracts and velocities will increase. Just after the bow boundary layers will develop at the bed and at the ship's keel. They grow in thickness in the direction of the ship's stern. Effectively, the current close to the bottom first increases and then decreases again as the boundary layer grows. As the amount of displaced water does not change, the current velocities at mid depth under the ship increase, and for small under keel clearances water will flow sideways from underneath the ship. Although the development of boundary layers was not the subject of this research, they do influence the measurement of the under keel velocities and the effective eroding force on the bed.

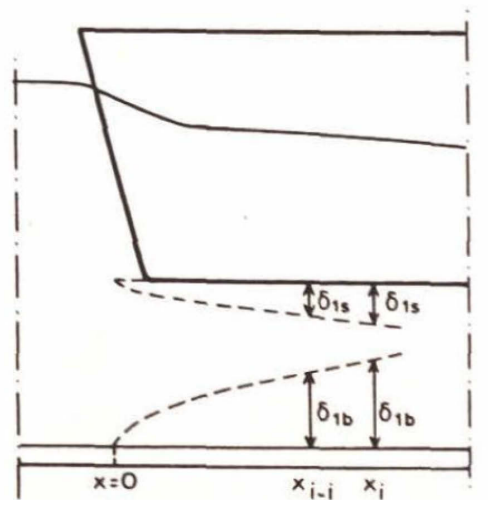

Figure 3. Growth of boundary layers at bed and keel. 


\section{MEASUREMENTS}

\subsection{Measurement location and conditions}

The measurement site is located in between 3 and 5 $\mathrm{km}$ 's from the southern entrance of the canal. This site was chosen for the following reasons:

- This part of the canal had already been dredged to the required minimum 4.9 meters water depth for future navigation.

- There was a minimum amount of gravel left on the clay layer, varying from 10 to $30 \mathrm{~cm}$.

- The prototype ship could turn in harbours both North and South of the location.

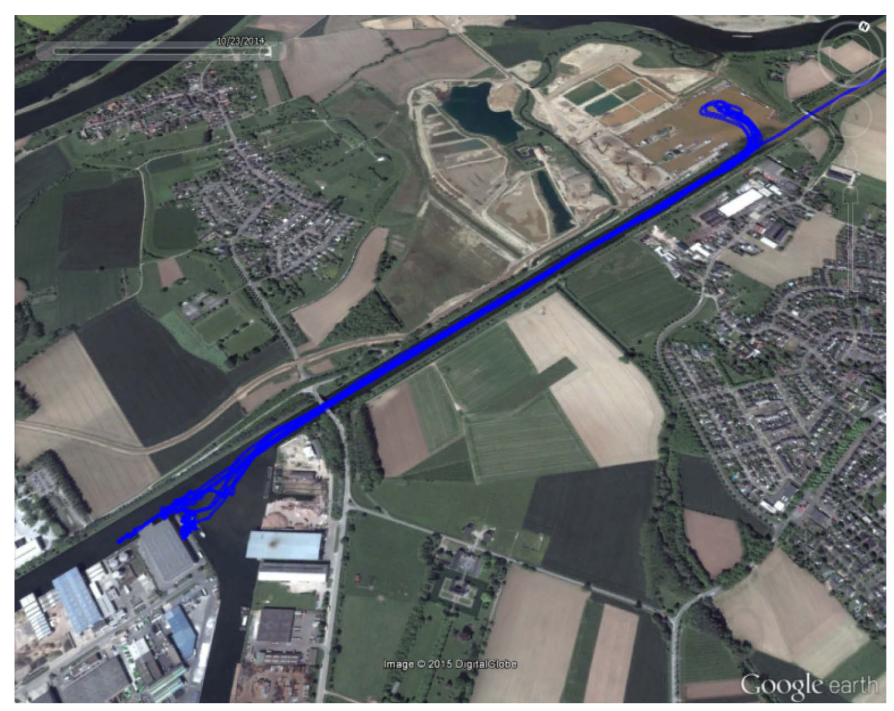

Figure 4. Measurement location with shiptracks of the barge (from AIS = Automatic Identification System) and the two turning points in the harbours. Source: Google earth.

At the selected measurement location the canal is only 45 meters wide, while in other parts the width is 70 meters. The available water depth between 4.9 and $5.2 \mathrm{~m}$ depends on the water availability and lock operation upstream and downstream from the measurement site.

On average the canal handles 4000 to 6500 inland cargo vessels each year. On top of that thousands of recreational vessels make use of the canal during the holidays. The experiments had to take place during the holiday season meaning it would hardly interrupt ongoing commercial shipping activities and the experiment itself would not be too much disturbed by the ongoing navigation.

\subsection{Measurement set-up}

The barge, dimensions 110 meters long and 11 meters wide, was loaded with sand to reach a draught of 3 meters. To create the draught of 3.5 meters which will be the permitted loading draught in the future, water tanks in the barge were filled. With a water depth of 4.9 meters and an anticipated sinkage up to
30 centimeters this resulted in 1.1 meter under keel clearance in which the current velocities were to be measured.

In this case the expected average return current flow velocities adjacent to the ship and computed with the Schijf method were in the order of $1 \mathrm{~m} / \mathrm{s}$ and the possibility of under keel currents of $4 \mathrm{~m} / \mathrm{s}$ was taken into account when choosing and setting up the instrumentation for the experiment.

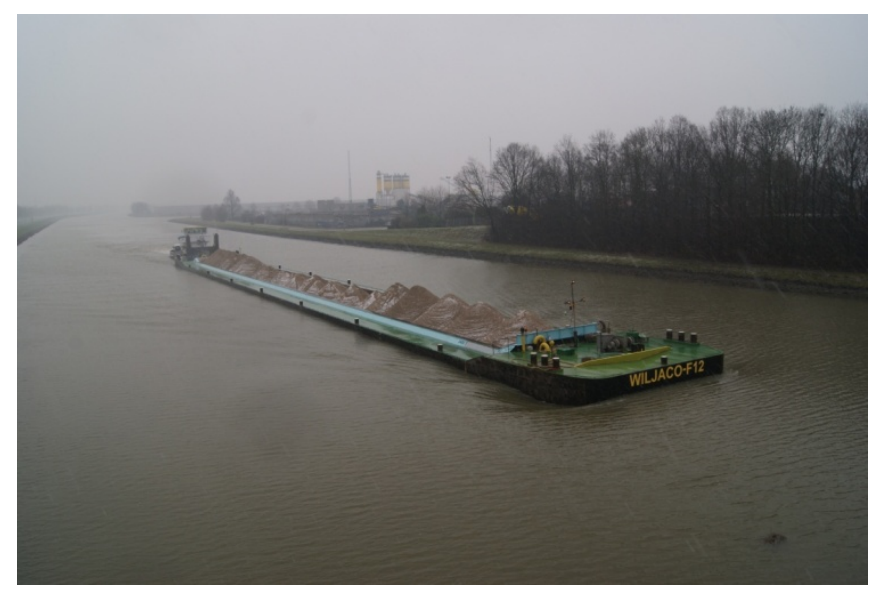

Figure 5. The push-tow barge combination Sandra F-Wiljaco F12 in a wide stretch of the Juliana canal.

Current velocities were measured using a Nortek Vector point current meter and a Nortek EasyQ profiler, both acoustics Doppler instruments. The instruments were mounted on a bracket. The point current meter was measuring with $2 \mathrm{~Hz}$ at a height of $0.26 \mathrm{~m}$ above the bed in a volume of $2 \times 2 \times 2 \mathrm{~cm}$. With the EasyQ it was possible to determine a current profile from $0.38 \mathrm{~m}$ above the bed of the canal up to the water surface or the ship's keel. The profile was segmented in $0.2 \mathrm{~m}$ cells. Due to the beams being positioned in one plane the measurements were only taken in a direction parallel to the channel axis.

The bracket was an open frame which was digged into the gravel bed in the middle of the canal by a dive team. This ensured both minimum influence of the bracket on the currents and maximum stability of the set-up. Signal and power cables were run to shore. The instruments were connected and operated from a single laptop situated on the dike next to the canal. The instruments were left on the bottom of the canal over a period of 10 days.

Note that the current velocities were measured only at one location $(\mathrm{km} \mathrm{3.7).}$ 


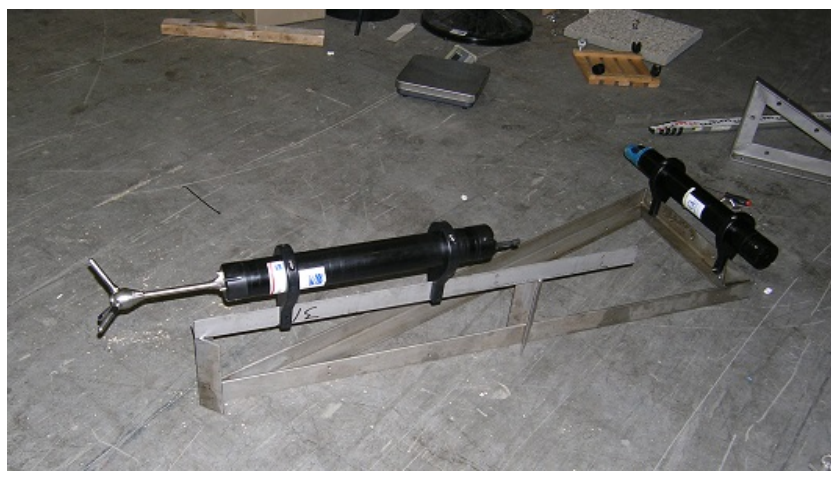

Figure 6. Bracket with Vector (looking sideways) and EasyQ (looking upward).

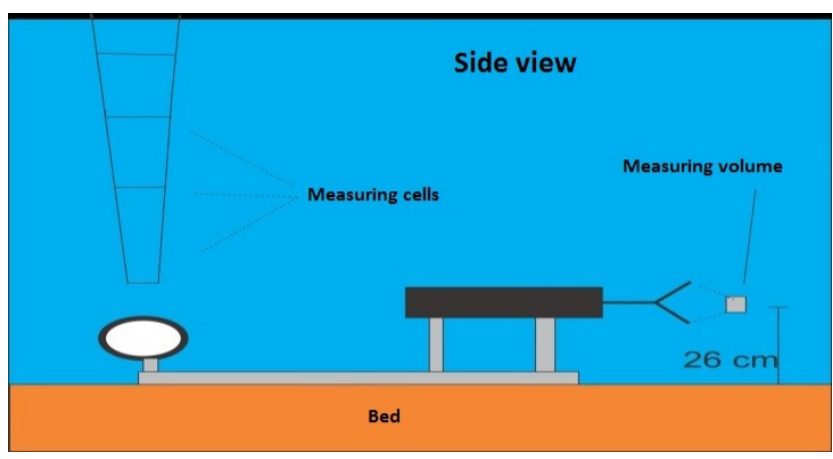

Figure 7. Positions of flow velocity equipment.

\subsection{Execution of the experiment}

The barge was run through the canal 60 times over a period of 5 days in both upstream and downstream direction. On one day (14 runs) the barge was loaded to a depth of 3 meters and for the other days it was loaded to 3.5 meters. The average speed of the barge was $1.9 \mathrm{~m} / \mathrm{s}$.

The other shipping traffic was guided and sometimes detained by an on-site traffic control ship. This way the barge could safely sail through the center of canal.

Severe erosion of the clay layer is and was not allowed so it was not allowed that the experiment could turn into a destructive test of the clay bed at any time and therefore the bed level of the test section was monitored by a survey ship 4 to 5 times a day using a multi beam echo sounder. The resulting difference in bathymetry was processed at the end of each day, after which it was decided whether or not to proceed the experiment.

\section{RESULTS}

\subsection{Flow velocities}

The 60 passages of the push-tow barge combination were logged and processed along with 25 other conventional ships that created a current of more than $0.5 \mathrm{~m} / \mathrm{s}$ at the bed. An example of the results is given in Table I.
Table 1. Example of measured maximum return currents for different ships.

\begin{tabular}{|l|l|c|c|c|}
\hline & Ship name & $\begin{array}{c}\text { Size } \\
1 \times \mathrm{w} \times \mathrm{d}\end{array}$ & $\begin{array}{c}\text { Speed } \\
\mathrm{m} / \mathrm{s}\end{array}$ & $\begin{array}{c}\text { Max. re- } \\
\text { turn } \\
\text { current } \\
\mathrm{m} / \mathrm{s}\end{array}$ \\
\hline 1 & Sandra F & $110 \times 11 \times 3$ & 2.3 & 0.91 \\
\hline 2 & Sandra F & $110 \times 11 \times 3.5$ & 2.1 & 1.26 \\
\hline 3 & Faraday & $110 \times 11 \times 2.6$ & 2.4 & 0.93 \\
\hline 4 & Westenwind & $105 \times 10 \times 3$ & 2.4 & 0.91 \\
\hline 5 & Combination & $110 \times 11 \times 3$ & 2.3 & 1.05 \\
\hline 6 & Jill F & $48 \times 7 \times 2.5$ & 3.3 & 1.18 \\
\hline 7 & Sandra F & $110 \times 11 \times 3.5$ & 2.0 & 1.25 \\
\hline 8 & Mover & $88 \times 11 \times 3$ & 2.2 & 0.66 \\
\hline
\end{tabular}

The maximum return current induced underneath the barge varied from $0.9 \mathrm{~m} / \mathrm{s}$ to $1.2 \mathrm{~m} / \mathrm{s}$ when it was loaded to 3 meters draught and from 1.2 to $1.6 \mathrm{~m} / \mathrm{s}$ when loaded to 3.5 meters draught.

Figure 8 shows velocity vectors as recorded 26 $\mathrm{cm}$ above the bed during one of the passages of the push-tow barge combination.

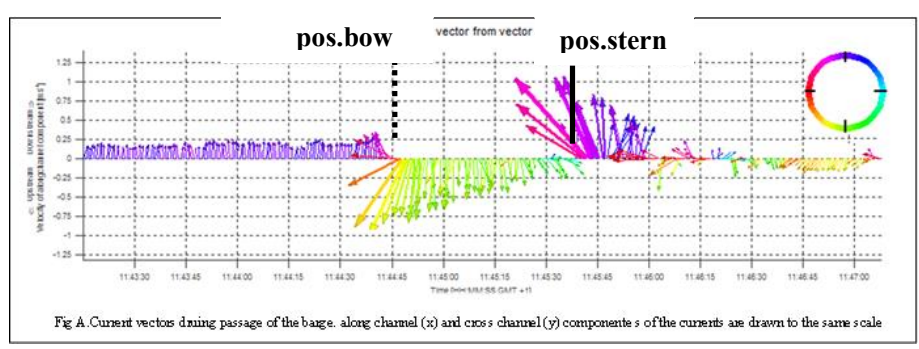

Figure 8. Size and direction of the flow velocities under the ship's keel.

This figure can be described as follows: before the passage there is a $0.2 \mathrm{~m} / \mathrm{s}$ natural current due to the discharge through the canal. In this case the barge sails in the direction of this flow. The barge creates a return flow which first flows slightly sideways. During the passage the current gradually decays. After the passage the current sharply turns around to the stern of the barge (see also Figure 2) After the passage there is a turbulent flow which takes time to settle. The whole event lasts less than a minute.

The measurements of the profiler were too noisy to determine reliable time series of the profile during a passage. For the sake of the analysis the measured currents in 3 cells over the depth of 38 to $98 \mathrm{~cm}$ were averaged to one value. This gave a stable result which could be compared and combined with results of the measurements by the point sensor. Figure 9 shows the current parallel to the canal axis of this averaged cells and the current closer to the bed during one passage. It shows a sharp increase in current at the beginning and as the passage progresses the 
current near the bed reduces by half while the current higher up is more or less stable over the passage. The reduction of flow at the bottom is attributed to the forming of the boundary layer at the bed.

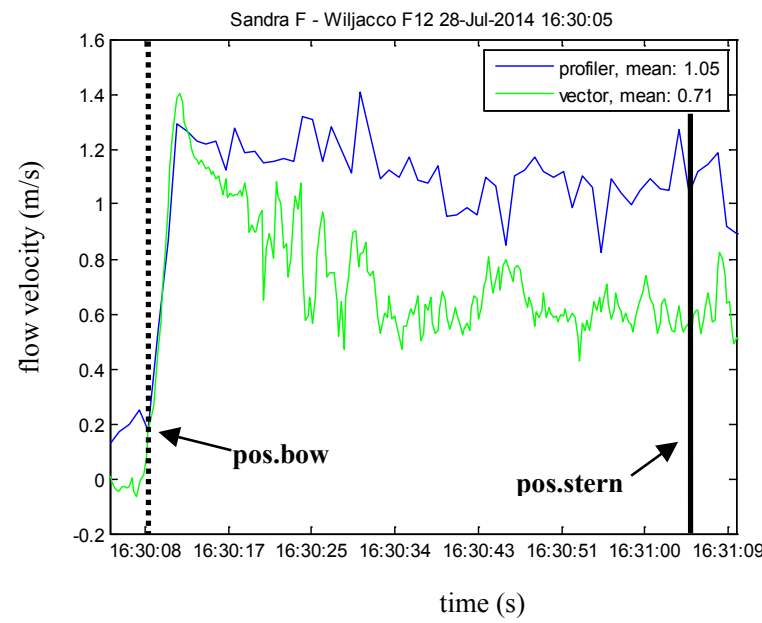

Figure 9. Currents parallel the canal axis $26 \mathrm{~cm}$ above the bed (green, lowest line) and averaged over 38 to $98 \mathrm{~cm}$ above the bed (blue, upper line).

The expected sideway flow as a result was already shown in Figure 8. This is a known phenomenon and comparing this field data with recent results from scale measurements from the laboratory is subject of future study.

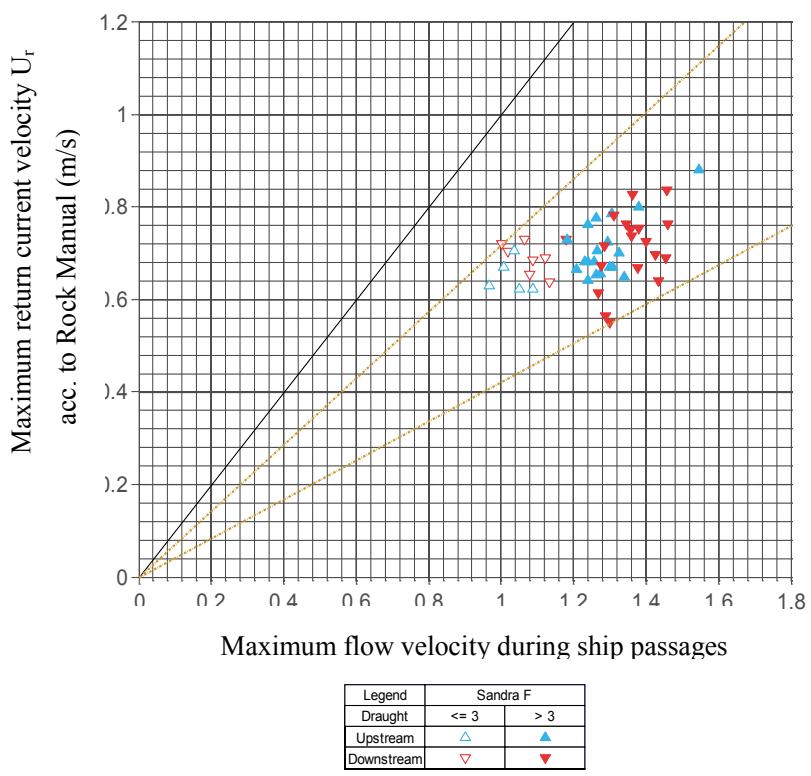

Figure 10. Relation between measured maximum return currents under the vessel and estimated mean return currents over the whole cross sections as calculated with (CUR/CIRIA/CETMEF, 2007) taking into account the natural flow velocity.

The measured maximum current under the pushtow barge combination was compared to the computed mean return current over the whole crosssections using the method of Schijf (Figure 10). On average the ratio is 1.6 if the barge was loaded to 3 meters and 1.8 in case it was loaded to 3.5 meters. These ratios can be used to predict the expected currents at other sites along the canal.
The currents generated by the push-tow barge combination loaded to 3 meters draugth are comparable to values seen at other inland ships with similar size and draught and therefore assumed reliable as a measure of average underkeel hydraulic loads. The measured currents created with a larger draught of 3.5 meters are a measure for the loads to be expected from future navigation.

\subsection{Bed erosion}

The bathymetric data were mapped on a grid with 0.5 by 0.5 meter cells. The reproducibility of the bathymetric measurements was established at $3.5 \mathrm{~cm}$ on average per cell.

The differences after each day were mapped. The differences between the start of the experiment and the end of the experiment is given in Figure 11. It shows an erosion path along the center of the canal and sedimentation in the areas more to the sides. It is concluded that due to the sideways currents induced by the push-tow barge combination the gravel moved from the center of the canal to the sides.

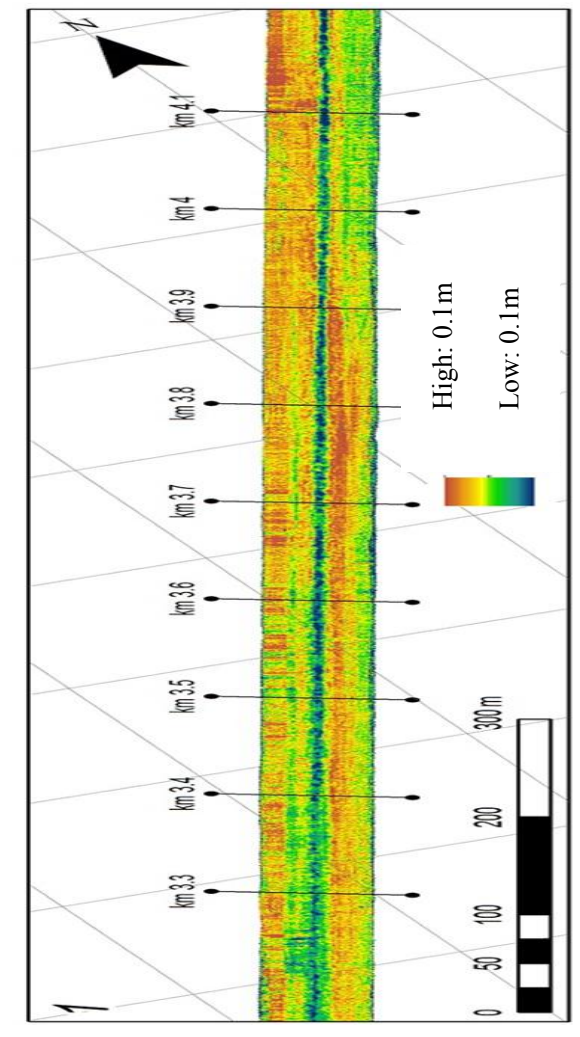

Figure 11. Plot showing the differences in bathymetry between the start and the end of the experiments.

The critical flow for erosion of bed material can be calculated using for example the relation proposed by Izbash (CUR/CIRIA/CETMEF, 2007):

$$
\frac{u^{2}}{2 g}=\frac{2}{k_{t}^{2}} D_{50} \Delta
$$


where $\mathrm{u}$ is the current velocity $(\mathrm{m} / \mathrm{s}), k_{t}$ a turbulence factor (-), $g$ the gravitational constant $\left(\mathrm{m} / \mathrm{s}^{2}\right), \Delta$ is the relative density of the material and $D_{50}$ the $50 \%$ point of the grain size distribution of the material (m).

Using (2) with a $D_{50}$ of $12 \mathrm{~mm}$, which was determined from a gravel sample at the experimental site, and a turbulence factor of 1.4 , the critical flow velocity can be estimated at 0.75 .

The erosion path deepened by approximately 1 $\mathrm{cm}$ with every 10 passages of the push-tow barge combination (Figure 12). At the end of the experiment the erosion varied along this path between 2 and $10 \mathrm{~cm}$ and was $6 \mathrm{~cm}$ on average. The downward trend had not yet levelled out. Thus, the bed was not yet in a new equilibrium. Based on these observations of the bed, it was concluded that the bed is not stable and will not be stable at loads expected in the future.

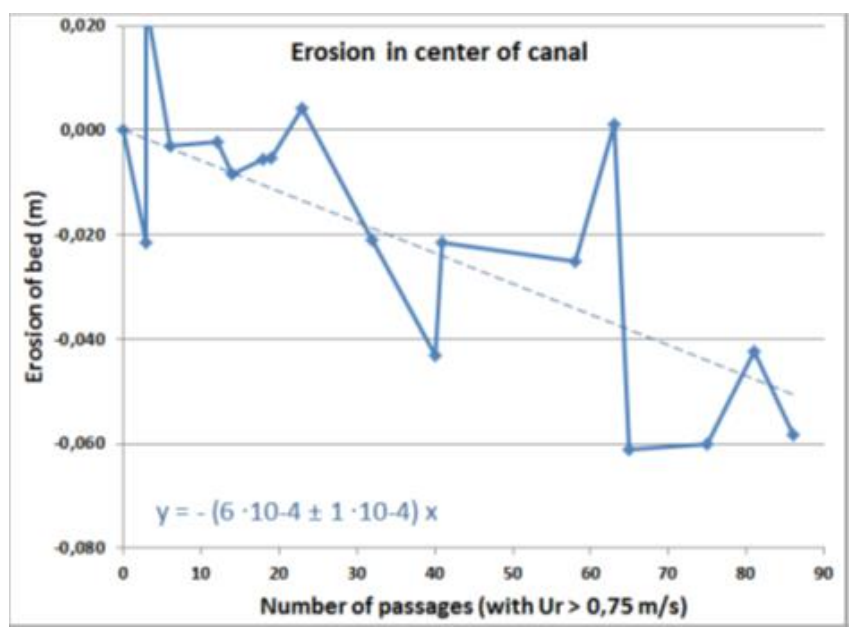

Figure 12. Deepening of the canal bed as function of the number of ship passages.

\section{ANALYSIS}

\subsection{Measured erosion versus theory}

The erosion due to the return current can be estimated with (Hoffmans \& Verheij, 1997):

$z_{m}=\left(\alpha U-U_{c}\right)^{2} \sqrt{\frac{t}{K \Delta^{1.7}}}$

with $U=U_{r}+U_{i}$

where $\mathrm{z}_{\mathrm{m}}=\operatorname{erosion}(\mathrm{m}), \mathrm{U}=$ maximum flow velocity $(\mathrm{m} / \mathrm{s}), U_{\mathrm{c}}=$ critical flow velocity $(\mathrm{m} / \mathrm{s}), U_{\mathrm{i}}=$ natural flow velocity $(\mathrm{m} / \mathrm{s}), U_{\mathrm{r}}=$ maximum return current velocity $(\mathrm{m} / \mathrm{s}), K\left(=330 \mathrm{~m}^{2} / \mathrm{s}^{4}\right)=$ erosion constant, $r_{0}$ $(=0.1)=$ relative depth-averaged turbulenceintensity (-), $t=$ time (hrs), $\alpha\left(=1,5+5 r_{0}=2\right)=$ turbulence-coefficient, and $\Delta(=1,65)=$ relative density
$(-)$. The duration $(\mathrm{d} t)$ per ship passage is estimated by:

$\mathrm{d} t=\frac{L}{V_{s}}$

where $\mathrm{L}=$ ship length $(\mathrm{m})$ and $\mathrm{V}_{\mathrm{s}}=$ ship speed $(\mathrm{m} / \mathrm{s})$. Subsequently, after $N$ ship passages the erosion depth reads:

$$
z_{m}=\left(\alpha U-U_{c}\right)^{2} \sqrt{\frac{N \mathrm{~d} t}{K \Delta}}
$$

Note: Equation (3) was derived for the timedependent growth of a scour hole. In this situation no scour hole development occurs, but a track develops meaning that the bed level will lower gradually. However, the erosion process is comparable and usable as indication of the expected bed level lowering. On the other hand, the model does not account for filling up the track by eroded sediment due to a ship sailing next to the track.

The equation has been applied with the 85 ship passages inclusive the 60 passages of the test ship (Sandra F) during the measurement period. The computation of the cumulative erosion is shown in Figure 13 together with the observed erosion in the center of the canal. The theoretical erosion for the 85 passages is about $11 \mathrm{~cm}$ which is $50 \%$ higher than the observed erosion of $6 \mathrm{~cm}$.

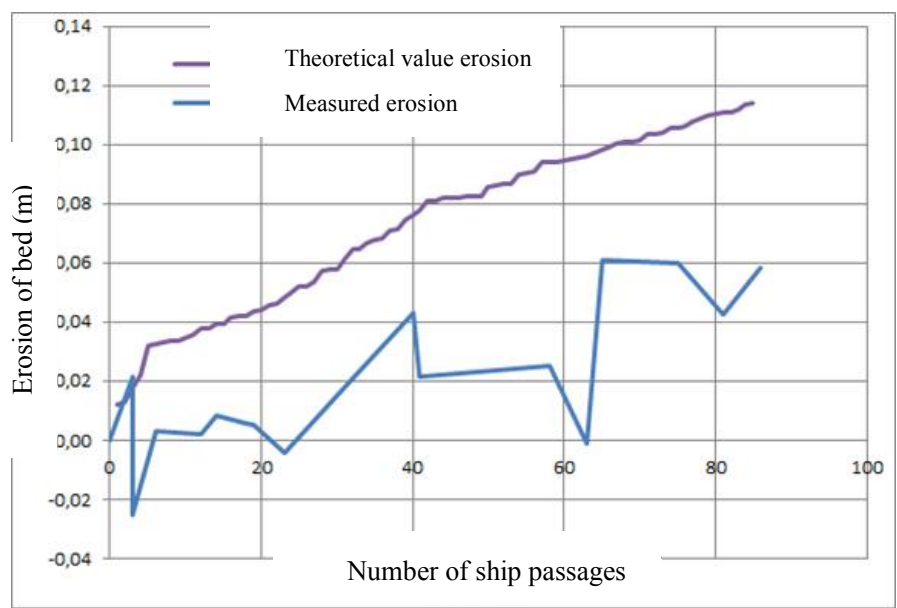

Figure 13. Theoretical and observed erosion of the canal bed as function of the number of ship passages (The theoretical value has been computed using the maximum measured return velocity and a critical flow velocity of $0.75 \mathrm{~m} / \mathrm{s}$ ).

There are two uncertainties not taken into account in this comparison:

1. Not all ship passages during the measurement period were measured. For example, ship passages during the night hours were not noticed. Subsequently, the computed erosion will be higher. 
2. On the other hand it is assumed in the computation that the effects of the individual ships can be added to each other. In reality, not all ships follow exactly the same course in the canal. This will reduce the computed erosion.

However, with this remarks the computed and observed erosion may seem to agree quite well.

\subsection{Comparison Juliana Canal tests with laboratory tests}

In 2014, within the framework of another research project, the flow velocities under the keel of a sailing vessel were measured (Robijns, 2014). Laboratory tests have been carried out with a conventional inland motor vessel and a push-tow barge combination for various keel clearances. The length scale of the experiments was 30 .

Figures 14 and 15 show qualitatively a different flow field under a ship for different keel clearances. The same phenomenon was observed in the Juliana Canal. Clearly, for a keel clearance of $0.09 \mathrm{~m}$ the flow continues under the keel up to the stern of the ship (Figure 14). For a small keel clearance of 0.015 $\mathrm{m}$ (model) the flow directly after the bow is directed to both sides of the ship (Figure 15).

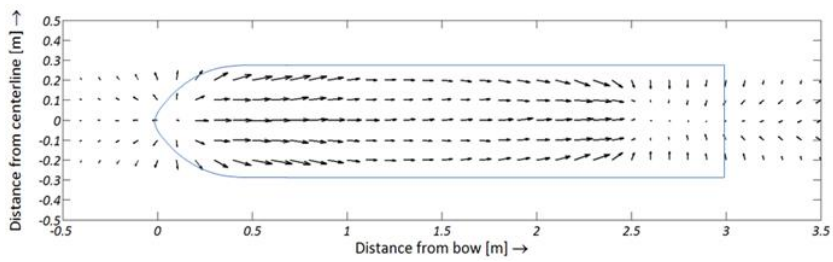

Figure 14. Flow field under the keel: keel clearance $0.090 \mathrm{~m}$, ship speed + natural current $0.80 \mathrm{~m} / \mathrm{s}$.

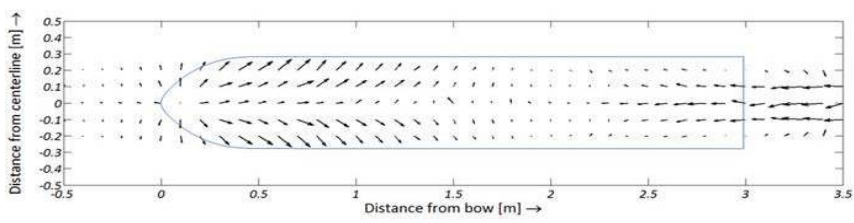

Figure 15. Flow field under the keel: keel clearance $0.015 \mathrm{~m}$, ship speed + natural current $0.65 \mathrm{~m} / \mathrm{s}$.

The results of the different tests can be compared. Figure 16 shows the maximum return current velocities as function of the keel clearance for inland motor vessels and push tow barge combinations. As expected, push-tow barge combinations generate higher flow velocities than inland motor vessels. This can be explained by the different shape of the ship's bow which is much more streamlined for motor vessels than for push-tow barge combinations.

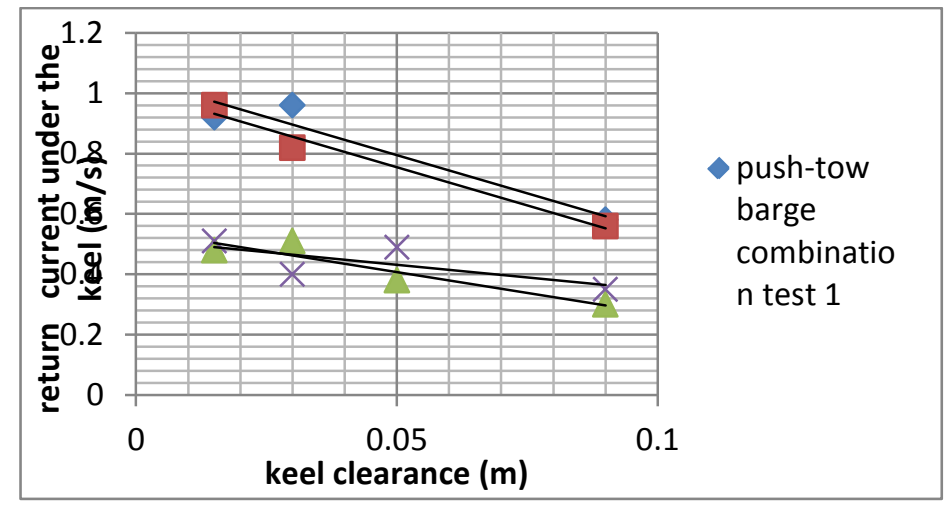

Figure 16. Maximum flow velocities under the keel of a ship as function of the keel clearance.

\subsection{Prevention of future erosion}

Because of the rather unique situation of the Juliana Canal, with its bed on a higher level than the surrounding area behind its dikes, an increase of the permeability of the existing bed is not allowed. This may cause instability of the dikes or an undesirable rise of the groundwater level in the surrounding area.

Mainly three different solutions are possible. A total replacement of the clay and gravel layer by a new impermeable material covered by a stable and erosion resistant protection might be necessary in case the lifetime of the clay layer decreases in the near future due to meio-macro fauna and/or in case a new stable bed protection requires a layer thickness leaving a too thin clay layer. In case the existing clay layer (in a sufficient thickness) can be kept in place, only a new stable bed protection layer is required. Finally also a maintenance solution can be considered, in which the canal bed has to be monitored frequently and the existing and replaced gravel will be shifted back in the eroded tracks. This choice process for different locations in the canal depends on several parameters and is still a subject of further study in which the life cycle costs will play an important role.

\section{CONCLUSIONS}

The induced peak velocities underneath the barge peaked at $1.5 \mathrm{~m} / \mathrm{s}$ and were $1.3 \mathrm{~m} / \mathrm{s}$ on average. Based on the observations of the bed, it can be concluded that the bed is not stable. Due to the currents induced by the barge the gravel moved from the center of the canal to the sides, leaving a 5 meter wide erosion path along the center of the canal. The erosion path deepened by 1 to $2 \mathrm{~cm}$ with every 10 passages of the barge. At the end of the experiment the erosion was up to $10 \mathrm{~cm}$ and the downward trend had not yet leveled out. Thus, the bed was not yet in a new equilibrium. It seems that this erosion can be estimated roughly with the equation of (Hoffmans \& Verheij, 1997). 
Given the fact that the ship-induced flow velocities expected of future navigation are comparable to the values measured in this prototype experiment, a negative impact on the underlying watertight layer is expected. In addition, the watertight clay layer is very inhomogeneous in both thickness and composition which makes it hard to estimate the timeframe in which erosion will lead to a serious problem, viz. a leaking canal. Subsequently, new mitigating measures to prevent future erosion have to be designed.

\section{ACKNOWLEDGEMENT}

The authors would like to thank all parties involved in the field experiment: Fransbergen BV (push-tow barge combination), Swets ODV (traffic control), IGL BV (bathymetric survey), Nortek BV (current meters), Twan (dive team) and the people from the Rijkswaterstaat patrol vessel " 8 ".

The work presented in this paper was commissioned by the Dutch Ministry of Infrastructure and the Environment.

\section{REFERENCES}

CUR/CIRIA/CETMEF. 2007. Rock Manual. London: CIRIA. report C683.

Hoffmans, G.J.C.M. \& Verheij, H.J. (1997). Scour Manual. Rotterdam: Balkema. ISBN9054106735.

Lenselink, R.J. 2011. Interaction between loaded barges and bed material. MSc thesis. Delft University of Technology, Delft.

Robijns, T. 2014. Flow beneath inland navigation vessels. MSc thesis. Delft University of Technology. Delft.

Schijf, J.B. 1949. Protection of Embankments and Bed in Inland and Maritime Waters, and in Overflow or Weirs. Lisbon: XVIIth International Navigation Congress. Section I pp. 61-78.

Stolker, C. \& Verheij, H.J. 2006. Ship-induced water motions beneath the ship's hull. Estoril, Portugal: 31th International Navigation Congress PIANC. 